\title{
A liberdade como desejo, a arte como resistência: autoritarismo e revolta em Manhã cinzenta, de Olney São Paulo e Contestação, de João Silvério Trevisan
}

\section{Freedom as Desire, Art as Resistance: Authoritarianism and Revolt in Olney São Paulo's Grey Morning and João Silvério Trevisan's Contestation}

\author{
Antônia Cristina de Alencar Pires \\ Instituto Estadual do Patrimônio Histórico e Artístico de Minas Gerais (IEPHA), \\ Belo Horizonte, Minas Gerais / Brasil \\ crisp563@gmail.com \\ Gustavo Tanus \\ Universidade Federal do Rio Grande do Norte (UFRN), Natal, Rio Grande do Norte \\ / Brasil \\ gustavotcs@gmail.com \\ Filipe Schettini \\ Centro Universitário UNA, Belo Horizonte, Minas Gerais / Brasil \\ filipe.schettini@outlook.com
}

Resumo: O cinema constrói uma diversidade de narrativas importantes para discutir sobre a humanidade e seus modos de relacionar-se. Muitas delas tratam do autoritarismo dos estados e sua antítese, que é a revolta, a resistência. Objetivamos analisar duas dessas narrativas fílmicas, intituladas Manhã cinzenta e Contestação, ambas de 1969 , tanto por serem filmes que tematizaram sobre o protagonismo dos estudantes frente ao autoritarismo e à violência das ditaduras, quanto por terem sido compostas por reutilização de imagens de arquivos fílmicos e jornalísticos, destes, sonoras de noticiários e clipagem de jornais. Essas narrativas serão lidas tendo como embasamento as teses benjaminianas, a fim de observar como foram construídas as temporalidades, 
a percepção dos acontecimentos, a construção da história. Essas narrativas suscitam reflexões e debates sobre os movimentos autoritários e repressivos, mostrando-nos a relação entre arte e política como um modo de colocar-se no tempo e no espaço. Assim, o engajamento de intelectuais e artistas, imbuídos da noção de que a arte pode ser um canal de mobilização efetiva, se mostra como uma forma de intervenção transformadora da realidade, e contestadora da grande narrativa da história.

Palavras-chave: cinema político; história; regimes autoritários; teses benjaminianas.

Abstract: Cinema builds a diversity of important narratives to discuss humanity and its ways of interacting. Many of them deal with state authoritarianism and its antithesis: revolt, resistance. This paper aims to analyze two of these film narratives, entitled Grey Morning and Contestation, both from 1969, for two reasons: they are documentaries that thematize students' protagonism against the authoritarianism and violence of dictatorships; they were composed by reusing images of filmic and journalistic files, newscast audios and newspaper clippings. These narratives will be read on the grounds of Walter Benjamin's theses, in order to observe how temporalities were constructed, together with the perception of events and the construction of history. These narratives raise reflections and debates on authoritarian and repressive movements, showing the relation between art and politics as a way of inserting oneself in time and space. Thus, the engagement of intellectuals and artists, imbued with the notion that art can be an effective channel for mobilization, stands as a form of intervention that transforms reality and challenges the grand narrative of history.

Keywords: political cinema; history; authoritarian regimes; Walter Benjamin's theses.

"A liberdade do outro estende a minha ao infinito." (Pichado nos muros de Paris, em maio de 1968).

Contra nossas vozes

Há muros

Contra nossa liberdade,

Guaritas,

Contra nossos lamentos

Há murros

$\mathrm{E}$ às vezes regulamentos,

Dependendo da conjuntura.

(“As prisões”, Alex Polari de Alverga, 1978). 


\section{Introdução}

A liberdade é um fundamento inalienável da Declaração Universal dos Direitos Humanos para uma convivência coletiva extra e intranacional. Esta, que em 2018 completou 70 anos, proclamou princípios sobre direitos universais a todas as pessoas do planeta, contemplando as relações entre o estado e as populações que estão sob sua jurisdição. A liberdade não pode ser reduzida a uma simples consideração de que ela vale por si mesma, não tendo compatibilidade com a liberdade dos outros. Ela é instrumental e conexa e, após a declaração, um direito universal, não sendo individual e desconectada de outras liberdades e das liberdades do outro.

Nesse sentido, a universalidade não pode, como se sugere nestes tempos irascíveis, ser pensada como ponto de dissolução da sociedade. Pelo contrário, por mais que a concepção e administração de um direito universal possa ser considerado um dos problemas comuns para uma sociedade a partir da visão interna de um estado, apenas uma concepção de direito de uma perspectiva universal (LAFER, 2015) - em garantias das liberdades como um direito a todos - possibilitará a coexistência dos indivíduos, embasando uma outra concepção de vida internacional, que aponte para as comunidades.

Em tempos de leituras rápidas, tempos em que golpes passam a ser tratados como revoluções, é necessário estabelecer maneiras de distinguir esses substantivos. Não se pode colocar dentro do mesmo campo de significação os golpes e as resistências contra as barbaridades, reduzindo-as. Golpes não são revoluções, como querem fazer crer os que tentam ora apagar o passado.

As revoluções pressupõem uma ética, enquanto os golpes são dados em nome da moral. As revoluções buscam romper com uma tradição de opressão, ao passo que os golpes, em nome "da paz e da honra nacional", atuam no sentido de mantê-la. Este texto trabalha com a ideia de revolução como a ação de revoltar-se contra a supressão de direitos, o estado de exceção, inerentes às ditaduras. Estas, em prol da manutenção do status quo das elites, forjam um "inimigo" da Nação, suspendem direitos e garantias fundamentais previstos nas Constituições (suspensão que denominam de "limitações") e reprimem violentamente os que se opõem às suas normas. 
Voltamos o olhar neste texto para as ações que se configuram verdadeiramente como revolucionárias, porque intentaram a interrupção do continuum da história, aproximando as ruínas que a compõem, enfatizando o presente como dilaceração e não como um presente com vistas a um futuro de "paz". Voltamos nosso olhar para as ações dos jovens de 1968, em sua luta, em sua resistência contra o autoritarismo, em seu desejo de liberdade, as quais, de forma eloquente, estão registradas na arte das imagens em movimento.

\section{Arquivos em movimento}

Tal como na literatura, o cinema é produtor de uma gama de narrativas que intencionam discutir por meio de suas imagens, o autoritarismo e sua antítese, a revolta, a resistência. Essas narrativas objetivam suscitar reflexões e debates sobre o tema, sublinhando, assim, a relação entre arte e política e o engajamento de seus realizadores, imbuídos da noção de que a arte pode ser um canal de mobilização efetiva, uma forma de intervenção transformadora da realidade circundante. Tanto na literatura como no cinema, essas narrativas formam uma espécie de série, que denominamos de "autoritarismo e revolta/resistência", segmentada em séries específicas. Constatamos isto no recorte "1968 e depois", uma seleção de filmes cuja temática é o autoritarismo e seu combate por meio de levantes propulsionados pelo desejo de liberdade e igualdade social, em um momento específico da História contemporânea: o ano de 1968. O referido recorte inclui produções que representam os acontecimentos daquele ano em vários países do mundo e, ao seu lado, produções que se inscrevem como resistência à ditadura civil-militar brasileira, em curso no mesmo período.

Além da mobilização e do engajamento proposto por essas narrativas, os filmes pertencentes à série em discussão, sejam eles ficções ou documentários, são perpassados por questionamentos e se configuram como registros da História no momento mesmo de seu acontecimento. Isto lhes confere o estatuto de "documentos", embora sejam documentos bem diversos das fontes documentais convencionais. Sobre isto, o historiador francês Marc Ferro refletiria, nos anos 1970, no ensaio "O filme: uma contra-análise da sociedade?". Nesse ensaio, Ferro defende os filmes como fontes históricas, apontando as transformações operadas na escrita da História desde o início do século XX, com o aparecimento da chamada História nova. (FERRO, 1975). 
Nessa História nova, o filme torna-se objeto e documento. Esse historiador dedicou-se sobretudo ao estudo das imagens produzidas pelo cinema, norteado pela compreensão de que essa arte, desde sua invenção e primeiras projeções pelos irmãos Lumière, inscrevera-se como discurso de representação da realidade, calcado numa narrativa, tanto quanto a história e a literatura. Ferro percebeu que por meio dos filmes era possível obter dados que através de outras fontes não se atingia. Ele passou a procurar nos arquivos fílmicos e nos filmes ficcionais, o que foi interditado/censurado pelas instituições oficiais em seus documentos.

Deste modo, Ferro busca das imagens cinematográficas fazer emergir a voz do Outro, o que implica na perda de primazia do Mesmo sobre a construção historiográfica. Ao eleger o cinema e suas imagens como fontes documentais, ele torna perceptível que a imagética cinematográfica propicia ao historiador criticar, reformular ou mesmo referendar juízos interpretativos e, assim, trazer à tona uma Outra história.

Ferro defende a ideia de que o cineasta, ao realizar um conjunto de imagens que tematizam um acontecimento histórico, assume, de certo modo, a persona do historiador e contribui para a discussão e a compreensão da história. Ele assinala a parceria historiador/cineasta, ou mesmo a troca de papéis entre ambos, como possibilitadora de uma maior disseminação da História, tornando-a mais inteligível e capaz de provocar a reflexão crítica dos sujeitos.

O cinema político exerce especial interesse em Ferro, assim como o engajamento dos cineastas. $\mathrm{O}$ autoritarismo e as contraposições a ele em imagens audiovisuais atravessa o pensamento ferriano. Ao tema, Ferro dedicou em particular o livro Revolts, revolutions, cinema (1989), no qual ele analisa o quão podem ser potentes e mobilizadoras as imagens produzidas pelo cinema sobre revoltas e revoluções e considera os filmes que as (re)apresentam como "agentes da História".

À luz do pensamento ferriano, é palpável nos filmes que fazem parte do recorte "1968 e depois" o estatuto de "agentes da História". Nesse recorte, ocupam esse estatuto como expoentes da subsérie dedicada aos levantes estudantis de 1968, os documentários franceses $O$ fundo do ar é vermelho (1977), de Chris Marker, Morrer aos 30 anos (1982), de Romain Goupil e o documentário experimental brasileiro, Contestação (1969), de João Silvério Trevisan. A eles, juntamos o média-metragem híbrido de ficção e documentário, Manhã cinzenta (1969), de Olney São Paulo, que além de tematizar o protagonismo dos estudantes contra o 
autoritarismo, desvela a ação violenta da ditadura civil-militar brasileira para reprimir a insurgência estudantil por meio da prática da tortura. São objetos deste artigo, os filmes de Olney e de Trevisan, que, entre outros pontos, têm em comum a ação revolucionária dos estudantes e as imagens neles (re)apresentadas, filmadas em 1968, na eclosão dos acontecimentos.

\section{Imagens-teses benjaminianas em Manhã cinzenta e Contestação}

Manhã cinzenta e Contestação foram realizados durante o acirramento da ditadura civil-militar, em curso há quatro anos, quando ocorreram em outros países os levantes que marcaram o ano de 1968. A onda de insurgências fora do Brasil reforçou o grito contra a opressão do regime brasileiro. Grito que ecoava em vários pontos do país desde o golpe, desde março de 1964, e que foi sufocado por violenta repressão, desaguando no Ato Institucional $n^{\circ}$ 5, de 13 de dezembro de 1968 que suspendeu todos os direitos e garantias dos cidadãos.

Enquanto arquivos em movimento, representações da revolta/ resistência contra o autoritarismo, como "agentes da História" no sentido ferriano, ambos os filmes apresentam um escovamento a contrapelo da História em suas tessituras. Sob este viés, observamos nas obras analisadas, como se verá na leitura das mesmas, imagens e reverberações das Teses benjaminianas. Estas, como se sabe, além de proporem um outro conceito de História, são um libelo contra o Nazifascismo, contra todos os regimes de exceção, tal qual os filmes analisados. Outra aproximação às Teses é a questão da simultaneidade entre acontecimento e registro, proposto por Benjamin numa perspectiva da História como uma soma de "agoras".

Coube a Olney Alberto São Paulo (1936-1978), um cineasta comprometido ética e esteticamente com as causas político-sociais, a maestria de mesclar uma gama de elementos para a elaboração de sua obra, realizada em um contexto sombrio e violento. $\mathrm{O}$ contato com o Neorrealismo Italiano foi fundamental em sua formação, no que se refere à sua técnica cinematográfica. Manhã Cinzenta possui uma visível relação com esse movimento italiano, principalmente no tocante à temática política e ao roteiro, híbrido de documentário e ficção, com a junção de cenas reais e encenadas.

A estética de filmagens fora dos estúdios e em locações reais, a mescla no uso de atores e não atores e a utilização da câmera na mão 
acompanhando a construção das cenas são atributos fortes do movimento italiano em questão, que foram influentes nos principais movimentos cinematográficos nas décadas de 1950 e 1960, como a Nouvelle vague francesa e polonesa, a New wave britânica e o Cinema novo brasileiro, do qual o filme de Olney faz parte. Entretanto, são as ideias de Sergei Eisenstein, cineasta e teórico russo, que estão mais presentes em Manhã cinzenta. Isto se verifica na larga utilização de elementos comuns no cinema formalista russo, que estudava, experimentava e valorizava a montagem. Este elemento base do cinema, no caso de Manhã cinzenta, é vital por dois motivos: para construção do sentido e da linguagem cinematográfica, e para desenvolver e estruturar a trama. Em relação ao primeiro item, observamos que Olney utilizou formas de montagem tais como as teorizadas por Eisenstein em A forma do filme (2002a). Neste livro, Eisenstein teoriza sobre a elaboração do material fílmico de forma equalizada, por meio da utilização de diferentes recursos presentes em um plano cinematográfico, como imagens, atuação dos atores, música, etc., em "conflito" com os outros planos, criando diversos efeitos como ritmo e metáforas. Como consequência desta construção, temos o segundo item, que é o desenvolvimento da estrutura e da trama fílmicas. Normalmente, no cinema narrativo clássico, isto se dá tendo como referência o cinema naturalista Hollywoodiano, mas em Manhã cinzenta, ocorre como no cinema moderno: uma narrativa fragmentada e não linear, gerando maior suspense e impacto no espectador, elaborando a sensação geral da obra e potencializando o seu discurso.

Manhã cinzenta, filmado em preto e branco, $35 \mathrm{~mm}$., inicia com a imagem de uma rua e uma seta apontando em direção ao espectador, ao som da canção "Gloria", que integra a Misa Criolla, composta pelo músico argentino Ariel Ramírez, que versa: "Gloria a Dios / en las alturas // y en la tierra paz a los hombres, / [...] paz a los hombres / que ama el Señor [...]" (RAMÍREZ, 1964). A canção inscreve-se irônica, naqueles momentos de intensa repressão do estado brasileiro, desde a "Marcha da Família com Deus pela Liberdade”, evento público organizado pela elite e pela classe média, em 1964, apoiado pela grande mídia, disseminadora da ideia de uma "ameaça comunista". "Glória" também aponta a dimensão trágica, a agonia que percorre o filme até seu desfecho, ocupando importante papel como elemento da montagem.

A montagem é fundamental no cinema em geral, e por mais que estilos como o naturalismo Hollywoodiano busquem maior descrição 
deste elemento em prol da narrativa e a mimese do Neorrealismo italiano elabore menos cortes para maior impacto das imagens com viés realista, ela é indissociável da linguagem do cinema. O filme de Olney busca justamente evidenciá-la, demonstrando-a como parte do sentido do filme e de sua linguagem. Assim, observamos em Manhã cinzenta a montagem do tipo "vertical", abordada em O sentido do filme (2002b), como o tipo de montagem que utiliza o elemento sonoro para sua complexa estruturação. Eisenstein traça um paralelo com uma partitura musical, onde mesmo com a sequência do desenvolvimento horizontal dela, são as ligações verticais que interligam " $[. .$.$] todos os elementos da orquestra dentro de$ cada unidade de tempo determinado". Como sugerido por ele, para atingir este efeito harmônico no cinema, são usadas como matérias-primas a imagem fílmica e a música, tanto como efeito sonoro-visual, como para construções de discursos, que no caso do filme de Olney, ganha força nas metáforas e nos jogos dialógicos.

Os protagonistas do filme são jovens estudantes, focalizados inicialmente em uma sala de aula. Entre eles está uma garota que dança ao som de uma canção tocada no rádio. Esta é um rock and roll, ritmo que emblematiza a rebeldia, o qual, associado à dança da moça, aponta para o desejo de liberdade dos que ali estão. A cena muda para passeatas (reais) dos estudantes, da resistência ao golpe, há confronto ao som da marcha "The Washington Post", de John Philip Sousa. Novamente a música atua como elemento da montagem, apontando a participação dos EUA no golpe brasileiro e a militarização do país.

Essas passeatas são as que ocorreram no Rio de Janeiro, desde o início de 1968. Em janeiro, o segmento estudantil protestara nas ruas contra a censura aos espetáculos teatrais. Os atos se intensificaram nas manifestações contra a mudança do restaurante Calabouço, um bandejão para estudantes carentes, no centro daquela cidade. Os frequentadores desse restaurante sempre foram comprometidos com as lutas políticas, fossem elas a melhoria da qualidade da alimentação, fossem lutas mais abrangentes, como os protestos contra a crescente repressão do regime golpista. Durante o jantar, em 28 de março, o Calabouço foi invadido pela polícia, que feriu estudantes e matou à queima-roupa Edson Luís de Lima Souto, um jovem de 17 anos. Novos protestos ocorreram nas ruas contra sua morte. Numa dessas passeatas, o ator Sonélio Costa (que faz o papel de Sílvio), foi inserido por Olney e discursa para a câmera, 
operada pelo diretor de fotografia José Carlos Avellar, o que se configura numa quebra radical das fronteiras entre ficção e realidade.

Além do registro das passeatas, Olney reutiliza sonoras de noticiários radiofônicos, como nas cenas em que o locutor anuncia uma manifestação de estudantes e trabalhadores contra o regime e a violenta invasão de um Liceu pela polícia, para barrar a passeata marcada para o dia seguinte. Há que se notar que essas sonoras propiciam as travessias a que se propôs Olney entre o ficcional e o documentário em Manhã cinzenta.

Na sala de aula, Alda, a moça que dança, diz: "É preciso fazer alguma coisa". O outro protagonista, Sílvio, emenda: "Não há mais esperança, tudo está perdido". Em seguida é mostrado um veículo onde estão presos esses dois jovens. Nesse momento há uma mescla de discursos conservadores. São ouvidas as vozes do locutor de rádio e de um soldado, numa espécie de jogral violento e intolerante. São as vozes do Mesmo, do Estado opressor, que se mantém por meio do discurso do medo e da culpabilização dos jovens que, segundo tais vozes, eram orientados para destruir a realidade, a "paz" e a "honra" nacionais. Assim, qualquer ato que contrariasse as forças de manutenção do status quo dominante era combatido. Combate este que ocorria por meio da aniquilação em cadeia da rede de significação das ideias progressistas, dos corpos políticos, pelo extermínio dos corpos físicos. É nessa direção que Alda, enquanto o Outro da História, afirma que algo precisa ser feito, para interromper a reação em cadeia, pois, levada ao cabo, significaria a morte da esperança, a desesperança.

Ao som da marcha militar "Semper Fidelis", de John Philip Sousa, um dos protagonistas lê o parágrafo final de $A$ peste, do filósofo argelino Albert Camus. A marcha associada ao livro de Camus - uma alegoria para o Nazifascismo - coloca-nos em fina ironia a questão do militarismo e seus correligionários, que são como os ratos vetores do bacilo da peste no romance camusiano. A peste é o estado de exceção, a intolerância e a violência dos homens. Segundo Benjamin (1994, p. 226), “o ‘estado de exceção' em que vivemos é na verdade a regra geral”. Esta compreensão, diz ele, é fundamental para enfrentar o Fascismo. Para isto, é necessário abolir a noção de progresso ao qual se une um inexorável crescimento humano, numa "marcha no interior de um tempo vazio e homogêneo" (BENJAMIN, 1994, p. 225). Esse modo de compreender o progresso, visto como uma norma na qual se põe fé, a partir de uma 
disposição linear do tempo, transforma a história num legado gestado no resulto de acontecimentos encadeados - esvaziados, imobilizados, eternizados pela noção de continuidade - dados ao presente e invalida o enfrentamento ao autoritarismo.

Assim, a montagem de Manhã cinzenta aponta para um outro modo de composição do tempo, não mais pensado em sua linearidade, mas como apresentação de tempos de acontecimentos diferentes, realidades históricas que inclusive são diluídas/apagadas na grande narrativa oficial. Na noção de progresso criticada por Benjamin, há uma concepção de "transformação" humana, transformação essa que não se constata. Para o filósofo, é necessário perceber que é a concepção de história que permite tais sobressaltos.

Questionar a ideia de progresso é questionar a ideia de marcha e de seu fundamento como norma histórica, para busca de uma ética para as relações humanas. Manhã cinzenta nos mostra uma outra maneira de compreender o tempo, a história, e o próprio progresso. Isto pode ser percebido em duas ideias de futuro expressas pelos personagens: uma relacionada ao presente convulsionado pela repressão, no qual o povo morrerá de bala e de fome, como diz o protagonista Sílvio; e um futuro igualitário, como sonha Alda, expresso na frase: "um país em que as crianças respirassem alegres e saíssem às ruas entoando um canto de amor".

Os objetos que simbolizam o progresso, o futuro, e que são utilizados em prol da opressão são expressos no filme na cena do julgamento dos jovens rebelados. Nela aparece um robô - representante da tecnologia, da objetividade, da cientificidade - que ironicamente é burocrático e conservador. Acusa e condena os jovens. O próprio julgamento pode ser visto como uma metáfora para o historicismo e suas grandes narrativas. Isto porque o julgamento é mesclado com as cenas de jovens numa cela, torturados, tentando organizar os acontecimentos. A violência contra as passeatas é retomada na fala de Sílvio, que diz que o povo está sendo metralhado pelos caminhos, por aderir aos protestos contra o golpe, lembrando ao espectador a retaliação do regime aos protestos da população civil contra os crescentes arbítrios do Estado autoritário.

As execuções realizadas no período da ditadura civil-militar brasileira não são debatidas ou relembradas suficientemente nos dias atuais. Isto se deve tanto ao fato de os executores e torturadores não terem sido julgados e condenados, quanto ao fato da "Grande História" relativa ao Brasil tratar superficialmente sobre esse período, tanto no 
ensino escolar quanto nas discussões acadêmicas. Sobre isto, tomamos o fragmento 3 das Teses sobre o conceito de História, de Walter Benjamin (1994, p. 223).

Neste fragmento, o filósofo alemão discorre sobre como a história só poderá ser completa ao incluir em seus relatos os pormenores e a fala dos oprimidos, rejeitando, assim, a já citada "Grande História", por que sua versão amplamente aceita é elaborada e validada pela classe dominante. Em outras palavras, filtrada por essa classe, por suas próprias convicções, focando apenas nos "grandes acontecimentos". Benjamin acredita que aos acontecimentos estão relacionados os pormenores, seja em suas causas ou em seus efeitos; Assim tudo se torna importante, pois os contextos, motivações e efeitos alteram nossas percepções sobre certos momentos históricos. Para isto seria necessário a história dos oprimidos ser "redimida", colocando todos os acontecimentos em perspectiva. Como escreve o filósofo: "O cronista que narra os acontecimentos, sem distinguir entre os grandes e os pequenos, leva em conta a verdade de que nada do que um dia aconteceu pode ser considerado perdido para a história.". (BENJAMIN, 1994, p. 223).

É interessante destacar que uma série de episódios relativos ao ano de 1968 ainda não constam das historiografias contemporâneas, ficando restritos à narrativas memorialísticas. É o caso da "sexta-feira sangrenta", como ficou conhecido o dia 21 de junho daquele ano. Este dia foi o ápice dos protestos que tiveram início com a morte de Edson Luís. Na data em questão, estudantes e populares se uniram contra a repressão. Foram levantadas barricadas na Avenida Rio Branco, semelhantes às do Quartier Latin, em Paris. O levante durou cerca de 10 horas e os dados não oficiais registram centenas de feridos e a morte de 28 pessoas. Destas, apenas quatro foram admitidas pelo Estado ditatorial. Em desagravo a este massacre, intelectuais e artistas organizaram a "Passeata dos cem mil’. (ANDRADE, 2008).

À prisão do casal Alda e Sílvio, seguem-se cenas de tortura de jovens num quartel. Estas cenas são mescladas com cenas de tomadas reais do Rio de Janeiro sob ostensiva repressão. Entre elas, cenas de confrontos entre a população civil e a polícia e a imagem de um cinema sitiado por policiais, cujo filme em cartaz, A noite dos generais (1967), de Anatole Litvak, fora exibido como forma de protesto pelo assassinato de Edson Luís. Na trilha sonora há o contraponto irônico-trágico entre os versos de "Glória" e uma marcha militar. A (re)apresentação de tais 
imagens assinalam, mais uma vez, o papel de "agente da História" assumido por Manhã cinzenta.

A revolta e a resistência dos estudantes são indiciadas na manchete real de um jornal sobre a repressão à uma passeata. $\mathrm{O}$ autoritarismo é emblematizado alegoricamente no estandarte da "Ordem da Concupiscência", cujo símbolo é uma seta que atravessa uma linha. A "Ordem" metaforiza as ditaduras brasileira e latino-americanas, (re) apresentadas pelo som do charango (instrumento andino tocado na Misa Criolla, de Ariel Ramirez). A linha que corta a seta simboliza os limites impostos pelos ditadores à população, especialmente aos jovens. Não é sem razão que à estas imagens, mesclam-se cenas de tortura, gritos, indagações e perplexidades dos prisioneiros no quartel. São representações das relações desiguais entre o estado autoritário e uma juventude desejosa de liberdade.

A morte por tortura e os julgamentos kafkianos aos quais foram submetidos os ativistas também são representados em Manhã cinzenta. "Todos estão mortos", diz Sílvio, referindo-se a seus companheiros. Durante o período da ditadura um número incontável de jovens foi morto mas para além das execuções efetivamente realizadas pelo regime, houve uma destruição ainda mais profunda da juventude, atacando sua essência e ideais, levando muitos ao suicídio.

Dentro do recorte "1968 e depois" existem dois exemplos fortes de autoextermínio, que são os casos retratados nos filmes Morrer aos 30 anos (1982), de Romain Goupil e Torquato Neto, todas as horas do fim (2018), de Eduardo Ades e Marcus Fernando. No primeiro filme temos a história de Michel Recanati, ativista político francês, de forte importância nas manifestações em maio de 1968, e que se matou em 1978 (aos 28 anos), ao pular na frente de um trem. No segundo filme citado, temos o personagem título, Torquato Neto, poeta, jornalista e letrista brasileiro que teve seus problemas psicológicos agravados seriamente por conta da ditadura, visto que era uma das figuras mais importantes da contracultura brasileira naquele momento. Torquato também se matou aos 28 anos, sufocado por gás dentro de seu banheiro. Estes casos ilustram como um estado de opressão constante afeta o emocional e o psicológico de quem se opõe à ele.

A voz do regime autoritário reitera as elites como donas do poder e, por conseguinte, donas da História. Em contraponto, as falas dos estudantes, que no filme representam os oprimidos, os inscrevem como 
sujeitos do conhecimento histórico. Para Benjamin, modificação da história não se dá como resultado de um progresso, mas pela suspensão de uma cadeia de acontecimentos que conduz a humanidade ao desfiladeiro. Essa ação de interromper esse movimento é realizada por ações de operários, trabalhadores e jovens revolucionários, cuja orientação se dá pela observação de um passado de ascendentes explorados, escravizados, e projeta-se nas lutas de revolta/resistência no presente, segundo a Tese 12 sobre o conceito de História (BENJAMIN, 1994, p. 228).

Entretanto, os oprimidos, que para Benjamin é a própria classe combatente, são destituídos de sua condição de sujeitos do conhecimento histórico. A cena em que um robô (alegoria da classe dominante), durante o julgamento de Sílvio e Alda, debocha do método de alfabetização criado por Paulo Freire, patenteia a manutenção do analfabetismo como instrumento de dominação pelas elites. Freire, como se sabe, foi preso e exilado pelo regime militar em razão da Campanha de Alfabetização do Governo João Goulart. Enquanto o robô fala em "arma”, Sílvio deitado, agonizante delira: "A-, mor", o que se relaciona à canção "É proibido proibir", de Caetano Veloso, que começa a ser ouvida: "Me dê um beijo, meu amor / Eles estão nos esperando / Os automóveis ardem em chamas." E são vistas várias cenas de Sílvio e Alda, reiterando os laços de afeto e de solidariedade entre os jovens que se revoltaram contra a opressão.

O título da canção de Caetano Veloso retoma a frase "Il est interdit d'interdire." pichada por estudantes nos muros de Paris, em maio de 1968, um dos lemas dos protestos daquele ano. O primeiro protesto estudantil iniciou-se questionando o conservadorismo institucional, logo ultrapassou os muros da universidade, integrando outras pautas de lutas, e motivou outros movimentos estudantis pelo mundo afora, estes que buscavam direitos civis, eram contra a guerra, contra o autoritarismo etc. Essa onda gestou uma movimentação cultural importante por parte dos estudantes, que perceberam, naquele momento, a força dos movimentos sociais (algo que historicamente já se sabia, haja vista as revoluções Francesa, do Haiti, Russa, entre outras), o que contribuiu, como parte da reação institucional, para a modificação da cultura política, pelo recrudescimento da violência dos estados. A esta frase liga-se mais uma centena delas, todas com uma dimensão política e estética, as quais compõem uma espécie de inventário de aforismos revolucionários mostrados na composição do filme $O$ fundo do ar é vermelho (1977), de Chris Marker. 
Em um jogo de tese e antítese, mesclam-se cenas de passeatas, torturas e uma voz que diz "passemos adiante, muito adiante", metaforizando o apagamento da História e da memória pela ditadura civilmilitar, que queimou documentos, arquivos e corpos. Desse apagamento restou Manhã cinzenta, que após sua proibição pelos órgãos censores, teve negativos e cópias destruídos, ficando apenas uma, escondida na Cinemateca do Museu de Arte Moderna (RJ), sendo localizada em 1994.

Ao som de "Señor tiene piedad de nosotros", volta-se a visão caleidoscópica, profusão de imagens diversas, do fuzilamento dos jovens, de uma sala de espera pós-tortura, em que uma jovem ensaia uma dança, e logo a cena volta para a sala de aula, do início do filme. Os estudantes escutam a notícia sobre a repressão. Alda diz: "Canalhas! [...] Mas eles me encontrarão de pé!", e começa a dança que vimos no início do filme. O média-metragem termina com o assassinato do casal, ao som da canção "Credo", da Misa Criolla: "Padre Todo Poderoso Creador De Cielo Y Tierra / Y En Jesucristo Creo".

Cabe lembrar que Olney é o único cineasta brasileiro que foi torturado em razão de sua própria obra, definida por ele, em entrevista ao jornal Última Hora, em setembro de 1969, Manhã cinzenta é "um canto de amor e liberdade". Porém, para o Serviço de Censura de Diversões Públicas, ela foi considerada "altamente subversiva". Em outubro de 1969, o cineasta foi preso, ficando recluso por dois meses, período em que foi torturado como seus personagens em Manhã cinzenta, o que levou Glauber Rocha a considera-lo herói e mártir do cinema brasileiro (ROCHA, 1981, p. 363). Olney ficou com sequelas físicas e psicológicas da tortura, vindo a morrer em 1978.

Contestação é um documentário curta-metragem em $16 \mathrm{~mm}$, montado a partir do reaproveitamento de imagens de arquivos fílmicos e jornalísticos. Ele permaneceu anônimo até 2013, quando a Cinemateca Brasileira digitalizou seus negativos, depositados ali pelo próprio Trevisan, muitos anos antes. A única cópia existente estava fora do país, nos arquivos da ISCRA (Image, Son, Kinescope et Réalisations Audiovisuelles), criada em 1974 por Chris Marker, entidade ligada ao Musée d'Art et d'Histoire, de Paris, em péssimo estado de conservação. Observamos entre o filme de Trevisan e de Olney aproximações, sobretudo no reaproveitamento de material midiático (imagens fílmicas, fotográficas e sonoras radiofônicas, no caso de Manhã cinzenta) e da música como elemento da montagem. 
Contestação é uma obra do cinema experimental, pertencente ao subgênero found footage, que não se refere a apropriação do termo feito pelo cinema Hollywoodiano contemporâneo e popular em filmes de terror, mas sim do verdadeiro uso do termo. Os filmes found footage existem desde o início do cinema, e se expandiram durante o período das vanguardas europeias, mas apenas a partir da década de 1950 é que este subgênero passou a ser largamente utilizado, tendo como expoente inicial o estadunidense Bruce Conner, com o filme A Movie (1958). O estilo e essência deste tipo de obra estão vinculados à montagem, a qual utiliza imagens de arquivo já existentes, estruturando-as em uma nova obra. Nas palavras de Rosa e Castro Filho, "O cinema found footage (reapropriação de arquivo), que, como gênero, ou procedimento, recicla, reedita e ressignifica imagens alheias, filmadas em outro tempo e contexto, e depois transpostas para um novo tempo e um novo contexto." (ROSA; CASTRO FILHO, 2016, p. 26).

Assim, Trevisan reprocessa imagens de vários atos de violência, confrontos, repressões em ditaduras, regimes autoritários e manifestações, de inúmeros países e épocas, mesclando-as com letreiros (interlúdios) entre alguns planos, e com manchetes reais de jornais. Toda esta estruturação através da montagem, além de fazer um recorte temático, cria também sentidos e significações próprias. No filme Contestação é visível o uso da "montagem intelectual", já teorizada por Eisenstein, que é um tipo de interação entre planos que remetem a um sentido fora do filme, o qual necessita de um conhecimento e entendimento cultural específico, sendo um "conflito-justaposição de sensações intelectuais associativas." (EISENSTEIN, 2002a, p. 86).

Com efeito, Contestação é um filme found footage que reconfigura imagens já existentes, a maioria delas já tendo sido amplamente divulgadas em todo o mundo, as quais são estruturadas pela "montagem intelectual", criando um recorte de momentos muitas vezes negligenciados pela "Grande História", como citado por Benjamin, obtendo assim uma associação facilmente perceptível, e potencializando através do ritmo dos cortes e trilha sonora um sentido comum em todos os planos: a luta contra sistemas opressores e ditatoriais, a luta incessante pela liberdade.

O filme inicia com uma advertência sobre o contexto de sua realização, sobre como a autoria teve que ser suprimida para preservação da vida do autor. As primeiras cenas são da base militar estadunidense, antiga Estação da Força Aérea de Cabo Canaveral, de onde partiram os satélites 
de controle de informação e os foguetes da NASA para o espaço. As cenas seguintes são a do solo da lua pisado, a bandeira hasteada no terreno lunar, e o aceno do astronauta "Buzz Aldrin". Destas imagens é possível pensar no progresso da ciência e da humanidade, no desenvolvimento dos Estados Unidos, frente ao desenvolvimento de outros países.

As cenas que se seguem - das pequenas rachaduras no vidro da janela e os buracos de balas, o movimento da câmera em um veículo a observar um cadáver seminu estirado ao chão, logo outro corpo, as primeiras barricadas de resistência - relacionam-se às anteriores, num jogo de ironia trágica, ressignificando-as, fazendo-nos gestar a primeira questão: o progresso da ciência é, de fato, o progresso da humanidade? Uma resposta possível de ser obtida aproxima-se das teses benjaminianas nona e décima segunda. (BENJAMIN, 1994, p. 226, 228-229).

O termo "Contestação", título do filme, aparece no letreiro entre setas que convergem nele. Esse termo tanto pode significar a prova com o testemunho de outrem, quanto um questionamento realizado, uma resistência, oposição, ou mesmo negar a exatidão de algo. Assim, tais setas tanto apontam a contestação que pode ser lida como um movimento contestatório, de resistência às atrocidades, e como um arquivo fílmico/ artístico implacavelmente interposto no encadeamento de acontecimentos da história brasileira, para contrapor a exatidão dessa grande história.

O filme trabalha de modo bem diferente com as temporalidades e territorialidades. De modo geral, as cenas de protestos que ocorriam e que constituem a montagem, são quase simultâneas àquele momento, em várias partes do mundo. Isto é, tratam de levantes contra as ditaduras gestadas no século XX.

Mesmo que os eventos tenham ocorrido, haja vista a proximidade da composição/montagem fílmica e as cenas de protestos, o fato de serem cenas de lugares diferentes para uma mesma questão, cada imagem de protesto passa a integrar um encadeamento discursivo dado pelo cineasta em sua montagem desconstrutora desse continuum da história, porque reata cada um daqueles acontecimentos, compondo uma outra "imagem do passado", numa cadeia de ruínas.

Em leitura de Manhã cinzenta (2017) tratamos dos estilhaços em sequência, na interpretação de que o tempo e o espaço da narrativa entravam em uma outra lógica, na temporalidade benjaminiana do tempo espiralar, com vistas a demonstrar como há uma repetição da história dentro de uma tradição das relações desiguais. $\mathrm{O}$ estilhaço ali, dos cortes e 
cenas, relacionava-se ao estilhaçamento dos corpos e mentes dos cidadãos brasileiros, tratando, portanto de fragmentação dos tecidos, fílmico e social, na narrativa, esta que compõe uma imagem caleidoscópica.

Em Contestação, o estilhaçamento se dá no fio da narrativa, com a intenção de destacar esse próprio fio e a ação de fiar. Isto significa dizer que as cenas (imagens de arquivos fílmico e jornalístico) por si só são os estilhaços, de várias histórias registradas no momento de seu acontecimento. Estes estilhaços compõem uma imagem do jogo de forças daquele presente. Essa maneira de composição dos documentários é chamada por Bill Nichols de "modo poético", em que há uma espécie de afastamento de certas convenções da montagem (renúncia de continuidades) na intenção de criar outros ritmos temporais e enredamentos espaciais. Assim, em leitura da nona tese benjaminiana, vemos que a composição e a montagem da narrativa do filme, por meio desses estilhaços, ironizam a construção da grande narrativa da história e sua construção por meio dos encadeamentos de acontecimentos (suas versões oficiais) em uma linha temporal. O filme de Trevisan perfaz outro caminho, mostrando-nos a subjetividade dos documentos em suas versões sobre os eventos, cujos elos são as ações violentas de repressão contra protestos pacíficos dos estudantes.

As cenas são dialógicas e se interagem, tais quais os protestos que questionam o golpe e as respostas de violência e destruição dadas pelo regime. As sequências mostram performances de discursos das autoridades da época (Hitler; Lyndon Johnson; Nixon; Papa Paulo VI; a rainha Elizabeth), ou cenas em que aparecem militares, em tropa, generais em diplomação, e clipagens de jornais. Entremeando tais sequências, foram inseridos letreiros que ajudam a compor a ideia do estilhaçamento, pois eles criam um sentido para essas sequências, buscando uma coordenação dos elementos dinâmicos das cenas. Esses letreiros organizam os eventos em uma dinâmica heterogênea, que possibilita a interpretação de tais acontecimentos. Eles orientam a uma mensagem dita ao final.

O primeiro letreiro a aparecer diz "É preciso", aparece duas vezes, cada vez com uma sequência de cenas. A primeira sequência é a das manifestações da Ku Klux Klan, portando faixas com os dizeres "Segregation forever" e a bandeira dos estados confederados (união dos estados escravistas do sul dos EUA, que não aceitaram a abolição da escravatura). Segue-se a repetição do letreiro, com cenas de uma multidão de pessoas, com faixas escritas "Civil Rights", reunidas para escutar um 
discurso de Martin Luther King; cenas de um protesto pacífico na Ásia. "Atrever-se" é o letreiro que aparece seguido de protestos do movimento negro estadunidense contra um massacre. Aparece a composição dos dois primeiros letreiros "É preciso atrever-se", e são mostradas cenas com jovens em passeata pacífica com mordaça negra na boca, simbolizando a censura. Outros protestos no mundo são mostrados. Há faixas com "go home yankys" e "estudias y lucha". (TREVISAN, 1969, 5:03-5:08). O letreiro diminui para "Atrever-se": jovens correndo, um rapaz negro sendo arrastado por policiais, e outro, branco, levado escoltado pelos braços. (TREVISAN, 1969, 5:13-5:23).

Aparece o letreiro "Pensar" e são mostradas cenas das ações policiais, de prisão, e a não desistência dos jovens. Esse é seguido do "Falar", que aparece duas vezes. Na primeira vez, com cenas de enfrentamento e agressão de jovens rendidos, para amedronta-los; depois seguido da contestação desses jovens, em várias localidades, como Ásia, África, Américas, pela violência e agressão desmedidas. Os letreiros "Agir" e "Ser temerário" são os próximos a aparecer. Esse primeiro relaciona-se às massas reunidas em protesto e a força de não retroceder diante das injustiças; aparece a bandeira estadunidense e o agir se dá na ação dos policiais armados, em aumento da repressão. O outro, liga-se à crença na mudança, no romper das cadeias de dominação; são mostradas passeatas contra a guerra do Vietnã, com a contrarresposta pela prisão de manifestantes do movimento negro estadunidense. O letreiro "Ser temerário" ultrapassa os limites da tela, a repressão torna-se mais violenta, com o uso de armamento e táticas de guerra.

Aparece a mensagem "Não intimidar-se", e a perseguição aos protestos continua sendo mostrada. Tal letreiro se repete mais uma vez, seguido de cenas de uso de força militar e de jovens não se rendendo. Os últimos são "Autoridades" e "Autoridades / Grandes Nomes"; a eles correspondem cenas que mostram grandes personalidades, já referidas acima, e os soldados como os executores do autoritarismo. As imagens desvelam o contraponto entre quem está por trás da política repressiva e quem executa, efetivamente, as ações violentas.

Nas cenas, soldados agridem covardemente jovens já aprisionados; aparecem outros sangrando (um dos jovens toma por trás uma coronhada na cabeça tão violenta que cai desmaiado. TREVISAN, 1969, 10:22). Imagens de Aviões, bombardeios, batalhões de policiais abrindo fogo; demonstração da força do estado autoritário contra protestos desarmados. 
Aparecem estudantes vietnamitas duramente destroçados pela repressão. Logo uma placa "Support our men in Vietnam" (TREVISAN, 1969, 10:36). Seguem-se cenas de um soldado piloto estadunidense, logo uma cauda de avião, fazendo manobra, essa placa reaparece e o avião atira em uma vila. Um jovem camponês é preso. Cenas aéreas de despejo de bombas, e são mostrados incêndios causados pelas explosões. A operação termina com um cogumelo de fumaça causado pelas bombas, e aparece Nixon com um sorriso de orgulho.

Aparecem clipagens de jornais, estes em mascarado apoio ao golpe brasileiro, noticiando as ocupações, as mortes. Vê-se uma pichação nos muros, contra o comunismo, a "ameaça" que ronda os sistemas capitalistas, justificando suas ações violentas para combatê-la. Uma das notícias mostra o apoio financeiro dos EUA ao golpe, por meio de empréstimos. As últimas cenas do filme mostram soldados que levam um jovem vestido de branco e amarram-no em um poste. Após sua execução, ao som de tiros, a mensagem composta pelas palavras dos primeiros letreiros: "É preciso atrever-se a falar, agir, pensar, ser temerário, e não intimidar-se com os grandes nomes nem as autoridades" (TREVISAN, 1969, 12:49). Este letreiro tem sua mensagem traduzida para o inglês, com cena entremeada por litogravuras de combates de séculos anteriores, e inicia-se a canção "Cambalache", na voz de Caetano Veloso: "Siglo veinte, cambalache / problemático y febril [...]" que trata da corrupção e exploração humanas. (TREVISAN, 1969, 13:17).

Seguem-se os letreiros com a mesma mensagem em francês, alemão, italiano, espanhol e russo. São mostradas outras gravuras. As primeiras litogravuras de revoluções, logo uma imagem de caveira com ossos trespassados (como piratas), encima dela, uma espécie de campo de luz envolvendo algo; e depois uma gravura com a bandeira dos EUA com uma cadeira elétrica com um crânio. A imagem da caveira reaparece mostrando que o que vai acima é a imagem de Nossa Senhora. Voltam os sons, gritos e sirenes. As últimas gravuras representam uma mulher em horror e, logo, a Comuna de Paris, pela igualdade e justiça. O letreiro muda

\footnotetext{
${ }^{1}$ Tango argentino composto por Enrique Discépolo, em 1934, a pedido de Ángel Mentasti, para compor o filme El alma del bandoneón, dirigido por Mário Soffici. Esse tango denuncia o período da história argentina chamado de Década Infame, que se iniciou com o golpe civil-militar de 1930. Houve crise no país e vários escândalos de corrupção dos golpistas. (CHAIA; LENCINA, 2017).
} 
a informação para: “Àqueles que no meu país e no mundo lutam para que o poder pertença igualmente a todos, e são por isso perseguidos, torturados e assassinados. Éste filme foi realizado por causa dêles." E os gritos cessam.

\section{Inventário de cicatrizes: considerações finais}

A liberdade, como um fundamento para as interações humanas, é antes um desejo de que todo o progresso da humanidade seja um desenvolvimento de uma ética que embase essas relações, para uma convivência pacífica, de respeito à diversidade, que permita a vida. A arte como atividade humana relacionada à manifestação da linguagem para representação do mundo, do pensamento humano, é política em seus modos - subjetivos - de enquadrar o tempo e o espaço. Assim, ela representa, no caso dos filmes analisados, a tentativa de interrupção do continuum da história, pela aproximação dos "cidadãos do mundo / habitantes da dor / em escala planetária” (ALVERGA, 1978, p. 51), em sua resistência ao autoritarismo e ao acirramento da violência perpetrada pelo estado. Tal experiência artística, pelo uso de imagens reais, esses arquivos em movimento, podem atuar, como disse Ferro, como "agentes da história", para narrar sobre a experiência do Outro.

Em suas formas e conteúdos, os filmes aqui (re)vistos abordam as ações revolucionárias contra a opressão. Como no cinema Formalista russo, buscam potencializar discursos e ideais através de ferramentas cinematográficas equilibradas pela montagem, seja na apropriação de imagens aparentemente fora de contexto (reconfiguradas num novo sentido), como em Contestação, ou na construção da mise-en-scène ficcionalizada, mesclada com a captação de momentos reais, como em Manhã cinzenta.

Esses filmes não se esgotam em si mesmos, porque tratam de algo caro ao ser humano: o desejo de liberdade face à opressão e a revolta/ resistência contra os opressores. Eles são perpassados por uma dimensão trágica, pois desvelam massacres, execuções, torturas, suicídios. Porém, dentro do jogo dialógico/dialético que lhes é inerente, são atravessados pelos sentimentos que unem os insurgentes durante as ações. São acervos trágico-poéticos de imagens de nossa História recente, como escrevem Brasil e Fagioli (2017). Em termos benjaminianos, eles são a constatação de que o Estado opressor vence sempre, por isto cabe ao historiador materialista escrever a História dos vencidos, dos que perderam a luta, 
para que as novas gerações a retomem. Para os sobreviventes da luta, esses filmes são o testemunho de sua fragilidade diante do aparelho repressivo do Estado. São inventários de suas cicatrizes, "vivas na memória / envoltas em cinzas, fios, cruzes", como nos versos de Alex Polari.

\section{Referências}

ANDRADE, Manoel de. 1968, A sexta-feira sangrenta, 2008. Disponível em: https://palavrastodaspalavras.wordpress.com/2008/04/29/1968-asexta-feira-sangrenta-por-manoel-de-andrade. Acesso em: 1 out. 2018.

ALVERGA, Alex Polari de. Inventário de cicatrizes. 2. ed. Rio de Janeiro: Comitê Brasileiro pela Anistia; São Paulo: Teatro Ruth Escobar, 1978.

BENJAMIN, Walter. Sobre o conceito de história. In: . Obras

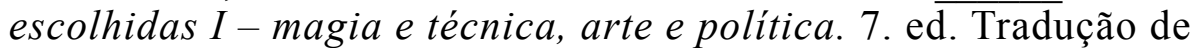
Sergio Paulo Rouanet. Prefácio de Jeanne Marie Gagnebin. São Paulo: Brasiliense, 1994. p. 222-233.

BRASIL, André; FAGIOLI, Julia. O fundo do ar é vermelho: a subterrânea matéria sensível da história. Significação, São Paulo, v. 45, n. 50, p. 79101, jul./dez. 2018.

CHAIA, María; LENCINA, Victoria Julia. Historia del Cine Latinoamericano y Argentino: El alma del bandoneón (Mario Soffici, 1935). 2017. Monografia (Graduação) - Universidad de Buenos Aires Facultad de Filosofía y Letras, Artes, Buenos Aires, 2017.

EISENSTEIN, Serguei. A forma do filme. Rio de Janeiro: Jorge Zahar, 2002a.

EISENSTEIN, Serguei. O sentido do filme. Rio de Janeiro: Jorge Zahar, $2002 b$.

FERRO, Marc (org.). Révoltes, révolutions, cinéma. Paris: Centre Pompidou, 1989.

FERRO, Marc. O filme, uma contra-análise da sociedade? In:

Cinema e História. Tradução de Flávia Nascimento. Rio de Janeiro: Paz e Terra, 1992. p. 79-115.

FERRO, Marc. O filme: uma contra-análise da sociedade? In: LE GOFF, Jacques; NORA, Pierre (dir.). História: novos objetos. Rio de Janeiro: Francisco Alves, 1975. [1 ${ }^{\mathrm{a}} \mathrm{ed}$. francesa, 1974]. 
GARCIA, Luiz. Contestação, 1969. Os fios de histórias de filme exilado. Revista Eco pós, Rio de Janeiro, v. 19 (Cinema experimental), n. 2, p. 84-96, 2016.

GOUPIL, Romain. Morrer aos 30 anos [Mourir à 30 ans]. França: 1982. Documentário, Cor., $95 \mathrm{~min}$.

LAFER, Celso. Direitos Humanos: um percurso no Direito no século XXI. São Paulo: Atlas, 2015.

MARKER, Chris. O fundo do ar é vermelho [Le Fond de L'Air est Rouge]. França: 1977. Documentário em cores, $180 \mathrm{~min}$.

OTTE, George. Linha, Choque e Mônada: tempo e espaço na obra tardia de Walter Benjamin. 1994. Tese (Doutorado em Literatura Comparada) Universidade Federal de Minas Gerais, Belo Horizonte, 1994.

RAMÍREZ, Ariel. Gloria (Carnavalito-Yaraví). In: RAMÍREZ, Ariel. Misa Criolla/Navidad Nuestra. Charango: Jaime Torres. Argentina: Philips, 1964.

ROCHA, Glauber. Revolução do Cinema novo. Rio de Janeiro: Alhambra/ Embrafilme, 1981.

ROSA, Carlos Adriano Jerônimo de; CASTRO FILHO, Cláudio Marcondes de Castro. Cinema experimental e informação: desafios para o entendimento. Eco-Pós, Rio de Janeiro, v. 19, n. 2, p. 14-37, 2016.

SÃO PAULO, Olney Alberto. Manhã Cinzenta. Produção: Olney Alberto São Paulo e Ciro de Carvalho Leite. Fotografia: José Carlos Avelar. Brasil, 1969. 22min, P\&B, $35 \mathrm{~mm}$.

SCHEEREN, Andréia. Tropical-melancolia: Caetano Veloso confinado na Bahia. 2011. Dissertação (Mestrado em Literatura Brasileira) Universidade Federal do Rio Grande do Sul, Porto Alegre, 2011.

TREVISAN, João Silvério. Contestação. Brasil: 1969. Documentário, P\&B.

Recebido em: 29 de novembro de 2019 Aprovado em: 9 de janeiro de 2020 